\title{
Development and Assessment of Ash Mortality Models in Relation to Emerald Ash Borer Infestation
}

\author{
Rachel E. Clark, Kayla N. Boyes, Lori E. Morgan, Andrew J. Storer, \\ and Jordan M. Marshall
}

\begin{abstract}
Emerald ash borer is a pest of North American ash that has caused significant mortality within its introduced range. The timeline for tree mortality, once infested by emerald ash borer, is variable for individual trees, with a small proportion surviving infestation. Using tree health assessments and signs of emerald ash borer infestation, researchers developed decision models to predict the probability of mortality. Two resulting models performed well at correctly predicting mortality ( $>83 \%$ correct) and significantly separating probability of mortality for those trees. Both models used diameter at breast height (DBH) and presence of bark splits, with one including percent crown dieback and the other including vigor rating (overall tree health assessment). A third model had reduced correct prediction of mortality, but was still potentially an effective model. Other tested models had shortcomings in prediction of mortality or in separation of probabilities of mortality. Using variables from three potential decision models, the year of mortality was modeled. However, specific year prediction was not as effective. Because of a wide range of external factors, prediction of a specific year of mortality may not be appropriate. Using $\mathrm{DBH}$ and rapid health and infestation assessment data, the authors were able to correctly predict ash mortality within a three-year period for the majority of trees within this study. Management strategies that use these models for developing hierarchical removal programs for infested ash may distribute financial and environmental costs over multiple years as opposed to mass removal of street and park trees.

Key Words. Agrilus planipennis; Ash; Decision; EAB; Emerald Ash Borer; Fraxinus; Pests; Tree Survival.
\end{abstract}

Emerald ash borer [Agrilus planipennis Fairmaire (Coleoptera: Buprestidae)] is a metallic wood-boring beetle that originated in Asia and was transported to North America, likely establishing in the early- to mid-1990s (Haack et al. 2002; Siegert et al. 2014). All North American ash species (Fraxinus spp.) are susceptible to attack by emerald ash borer and it has caused significant mortality-estimated at 23 million trees in natural forests to 850 million trees in natural and urban forests (Poland and McCullough 2006; Marshall et al. 2013). Ash mortality has a substantial impact on street and park tree management, with billions of dollars (USD) invested in tree removal and replacement (Poland and McCullough 2006; Kovacs et al. 2010). Additionally, the rapid loss of trees may have negative public health impacts (Donovan et al. 2013). Retaining trees that may not succumb or developing hierarchical replacement plans to retain urban forest cover may alleviate both economic and health issues.

Detection strategies for emerald ash borer have been employed with a focus on signs of infestation and trapping (e.g., Crook et al. 2008; Marshall et al. 2009; Marshall et al. 2010). Once established populations are detected, implementation of management is oftentimes labor-intensive and costly, with substantial impact to the surrounding landscape (Poland 2007; Sargent et al. 2010; Donavan et al. 2013). While some less-intrusive management techniques are in practice and others are in developmental stages (e.g., insecticide application, host specific parasitoids), efforts to remove hazardous trees following emerald ash borer infestation and subsequent mortality are necessary (de Groot et al. 2006; Yang et al. 2008; Mota-Sanchez et al. 2009; Smitley et al. 2010a; Smitley et al. 2010b). Additionally, the widespread use of insecticides for emerald ash borer 
control may have wide-reaching impacts, including contamination of terrestrial and aquatic ecosystems (Kreutzweiser et al. 2007; Szczepaniec et al. 2013).

Decision models are useful in incorporating continuous numerical and categorical data, handling non-linear relationships effectively, and allowing for missing values (Fayyad and Irani 1992; Friedl and Brodley 1997). To avoid confusion in the data and interpretation, researchers of the current study omit the term 'tree' from the model technique, although it is the commonly used term. Use of the terms 'branching,' 'pruning', and 'rooting' are specific to the model type, and should not be confused with forestry techniques. Within areas of emerald ash borer infestation, signs and symptoms of attack (e.g., bark splits, exit holes, woodpecker activity, epicormic shoots) provide rapid, categorical assessment of individual tree infestation (de Groot et al. 2006). Couple these signs with ash health characteristics and the framework for decision model development is in place, rapidly assessed, and effectively deployable. The objectives of this study were to 1 ) develop management decision models based on multiyear health and mortality assessments, 2) assess those models using distinct data sets, and 3) test the hypothesis that rapid health and infestation assessments can provide predictability to ash mortality.

\section{MATERIALS AND METHODS}

\section{Tree Assessments}

Mature ash were identified at five Huron-Clinton Metroparks in metro Detroit, Michigan, U.S., initially via helicopter survey and then through ground verification (Marshall et al. 2013). Trees were identified to species, diameter at breast height (DBH) was measured, and assessments of percent crown dieback (5\%-100\%) and vigor rating (1-6, Millers et al. 1991) were performed for June-August 2009 (Year, $\mathrm{n}=203$ ). Researchers also noted signs and symptoms of emerald ash borer infestation (bark splits, exit holes, woodpecker activity, and epicormic sprouting). Bark roughness was assessed using digital images as described by Marshall et al. (2013). Roughness values were a count of black pixels after images were converted to binary, black-white images. Roughness groups were then categorized into five equal interval groups based on minimum and maximum roughness values for pooled trees. For all trees, mortality was assessed each year in July 2010-2012 (Year ${ }_{1}$, Year $_{2}$, and Year $_{3}$ ).

Mature ash were identified at three city parks in Fort Wayne, Indiana, U.S., via ground surveys during July 2011 ( Year $_{0}, \mathrm{n}=91$ ). Methods for species, $\mathrm{DBH}$, dieback, vigor, and signs and symptoms were similar to above. Roughness groups defined from images were used to categorize trees from the Indiana parks. Mortality was assessed in July 2012-2014 (Year ${ }_{1}$, Year ${ }_{2}$, and Year $_{3}$ ).

A subsample of trees from both Michigan ( $\mathrm{n}$ $=56)$ and Indiana $(\mathrm{n}=18)$ were used to calculate ten-year and five-year growth rates prior to Year. For each tree, two cores were collected perpendicular to each other with a $4.5 \mathrm{~mm}$ diameter increment borer at breast height. Ring widths were measured to the nearest $0.01 \mathrm{~mm}$ and ring basal area $\left(\mathrm{mm}^{2}\right)$ was calculated based on Year $\mathrm{DBH}$. Mean annual growth rates were calculated for the five years and 10 years prior to Year ${ }_{0}$.

\section{Decision Model Development}

Trees from Michigan and Indiana were pooled and randomly placed into model development $(n=146)$ and model assessment categories $(n=148)$. Trees used in model development and assessment were unique individuals and overlap between the two categories did not occur. T-tests were used to compare $\mathrm{DBH}$ and percent crown dieback for trees that survived and died within the study period. Mood's median test was used to compare bark roughness group and vigor rating between trees that survived and died within the study period. Decision models were developed through recursive partitioning using rpart and rpart.plot packages in $\mathrm{R}$ (version 3.1.1, The R Foundation for Statistical Computing) with inputs of species, bark roughness group (1-5), $\mathrm{DBH}(\mathrm{cm})$, bark splits ( 0,1 absence, presence), exit holes $(0,1)$, woodpecker activity $(0,1)$, epicormic sprouting $(0,1)$, vigor (1-5), percent crown dieback $(5 \%-100 \%)$, and growth rate (average per year increase in $\mathrm{DBH}$ ) as independent variables and mortality [alive (0), dead (1) during the threeyear period] as the dependent variable. The recursive partitioning approach to model development allows for the input of numerous categorical and continuous variables with the final product of the approach being truncated (i.e., pruned) to a set complexity parameter, which limits the 'cost' of 
adding another variable to the model. Here, this cost is defined as the model variance (i.e., how well the model fits the data). By pruning the subsequent models to a set complexity parameter, researchers reduced the number of variables while maintaining variance. As such, the following list of models provides the variables that were inputs into the recursive partitioning. Resulting models were pruned to a complexity parameter of 0.02 and may not have included all input variables. The initial model included all variables as inputs $\left(\right.$ Model $\left._{A}\right)$. Subsequent models were developed with the inclusion and exclusion of selected variables, including: excluding dieback $\left(\operatorname{Model}_{\mathrm{B}}\right)$; excluding dieback and vigor (both of which require additional training for technicians to produce data within quality control standards, Mod$\mathrm{el}_{\mathrm{C}}$ ); including only data that may already exist in a management database (species, $\mathrm{DBH}$, and growth rates, Model $_{D}$; Roman et al. 2013); including only ten- or five-year growth and variation data (Model ${ }_{\mathrm{E}}$ and Model $_{\mathrm{F}}$, respectively); including only species and $\mathrm{DBH}\left(\right.$ Model $\left._{\mathrm{G}}\right)$; and including signs and symptoms with $\operatorname{Model}_{G}\left(\operatorname{Model}_{H}\right)$.

\section{Decision Model Assessment}

Decision models produced in the development phase resulted in probabilities of mortality. Following each of the resulting model branching, probabilities of mortality were assigned to each model assessment tree, which were then compared using a t-test for each model between trees that survived and those that died during the study period. Additionally, probabilities were converted to categorical data $(0,1$ predicted survival, mortality) with trees $>0.65$ probability of mortality categorized as dead. Akaike information criterion (AIC) was calculated for each model using binomial likelihood function to identify goodness of model fit for assessment trees. AIC allows for comparison of models, with lower AIC typically indicating a better model, which is influenced by the number of variables included (i.e., increase in variables leads to an increase in AIC) and error (i.e., increase in error leads to an increase in AIC). Those models with the best fit (i.e., low AIC and high percent correct prediction) were used to select variables to predict mortality year (1-3 after initial assessment).

\section{Mortality Year Model}

Using the decision criteria from the top three models (combination of greatest correct prediction and lowest AIC), a mortality year model was produced to identify the effectiveness of predicting a specific mortality year within the study period. Variables used as input to the recursive partitioning were those that occurred in the top three decision models. In both development and assessment, only those trees that died were used. As with the other model assessments, percent correct prediction was used to assist in identifying the goodness of model fit. Analysis of variance was used to compare the predicted mortality year between actual mortality years with Tukey's HSD as a post-hoc test. Statistical analysis was conducted using the base package in $\mathrm{R}$.

\section{RESULTS}

\section{Decision Model Development}

Of the trees selected for model development, 12 trees were dead in Year $_{1}, 54$ in Year $_{2}$, and 3 in Year. $_{3}$. Trees that died were significantly larger and with more crown dieback than trees that survived (Table 1). While the median bark roughness for both live and dead trees was the same as the overall median (2, Table 1), $68.1 \%$ of dead trees and $38.9 \%$ of live trees had bark rougher than that median. The overall median vigor was 1 , with $76.8 \%$ of dead trees and $12.9 \%$ of live trees in poorer health than the median. Finally, displayed signs of emerald ash borer attack was not independent of tree mortality, with trees that died having a greater proportion of at least one sign (e.g., bark splits, exit holes, epicormic sprouting, woodpecker activity).

Eight decision models were produced from the tree assessment data collected in Year ${ }_{0}$ for trees in Michigan and Indiana (Figure 1; Figure 2). Model $_{\mathrm{C}}$ and Model $_{\mathrm{H}}$ resulted in identical decision models. Model ${ }_{D}$ and Model $_{G}$ included additional variables as inputs, but only $\mathrm{DBH}$ was included after pruning to a complexity parameter of 0.02 . Because these models resulted in identical decisions, they were included for completeness.

\section{Decision Model Assessment}

Of the trees selected for model assessment, 13 trees were dead in Year $_{1}, 50$ in Year $_{2}$, and 4 in 
Table 1. Model development trees that survived and died during 2009-2012 in Huron-Clinton Metroparks, Michigan, and 2011-2014 in City of Fort Wayne Parks, Indiana.

\begin{tabular}{|c|c|c|c|c|c|c|}
\hline Development tree & Count & $\mathrm{DBH}$ & Crown dieback & Bark roughness & Vigor & With signs/symptoms \\
\hline Live & 77 & $16.5(1.3)$ & $10.5(1.6)$ & 2 & 1 & $43(55.8)$ \\
\hline Dead & 69 & $26.3(2.3)$ & $37.8(3.4)$ & 2 & 2 & $62(89.9)$ \\
\hline Test $^{\mathrm{z}}$ & & -3.9 & -7.41 & 12.41 & 60.43 & 20.84 \\
\hline$P$-value & & $<0.001$ & $<0.001$ & $<0.001$ & $<0.001$ & $<0.001$ \\
\hline
\end{tabular}

${ }^{\mathrm{z}}$ Mean comparison with Student's t-test for means ( $\mathrm{DBH}$, crown dieback = 1-tailed); Mood's median test for bark roughness and vigor; and $\chi^{2}$ test for signs/symptoms.

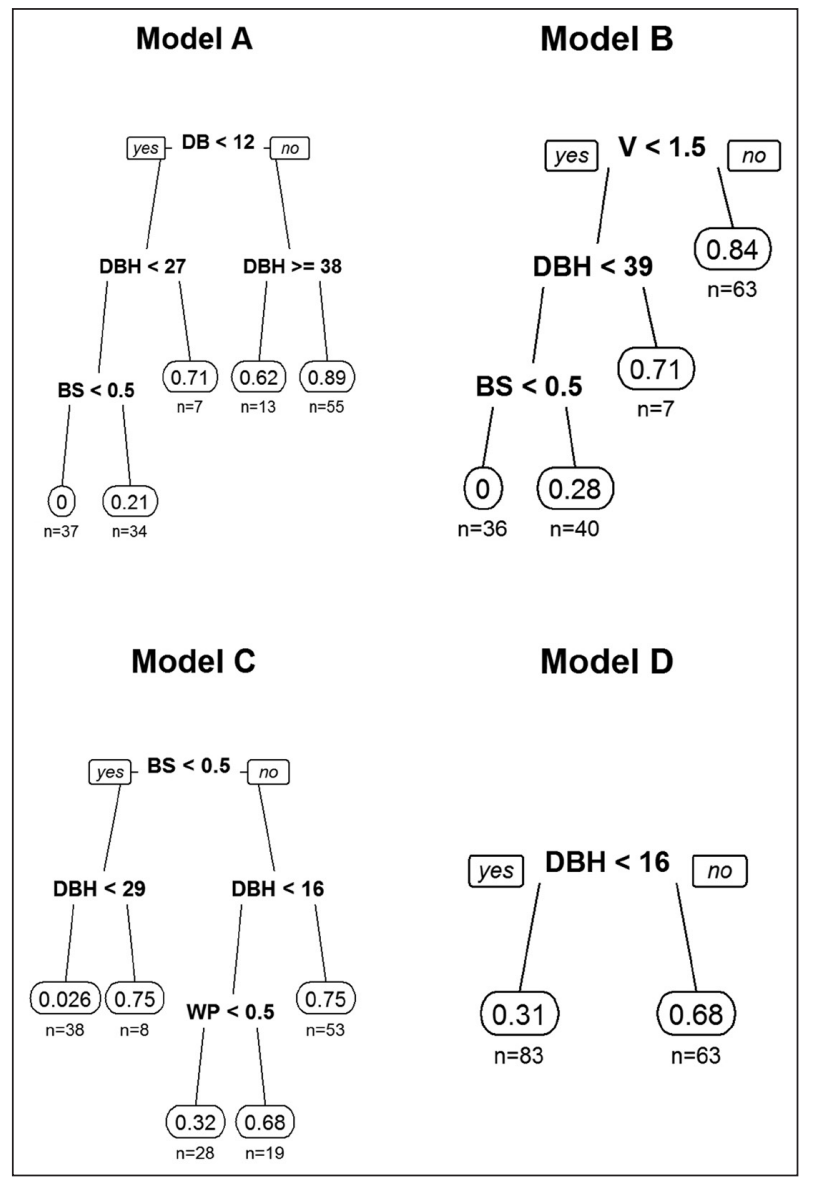

Figure 1. Graphical representation of decision models A-D developed with trees from Huron-Clinton Metroparks, Michigan, and City of Fort Wayne Parks, Indiana. Number of trees that reached the terminus of a branch is presented below the probability of mortality in ellipses. Variables include DB = percent crown dieback; $\mathrm{DBH}=$ diameter at breast height (cm); BS = bark splits; WP = woodpecker activity; V = vigor rating.

Year $_{3}$. These results were comparable to the number of trees dying each year in model development. Additionally, differences in the variables for trees that died and lived followed similar patterns as in the model development phase; trees that died were significantly larger and with more dieback; they were more likely to have rougher bark, poorer

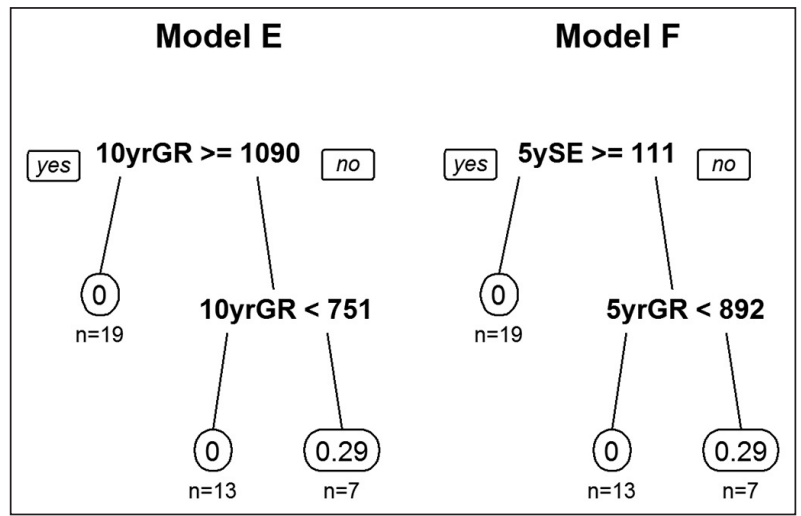

Figure 2. Graphical representation of decision models $E$ and $\mathrm{F}$ developed with trees from Huron-Clinton Metroparks, Michigan, and City of Fort Wayne Parks, Indiana. Number of trees that reached the terminus of a branch is presented below the probability of mortality in ellipses. Variables include 10yrGR = mean ring basal growth for 10 years $\left(\mathrm{mm}^{2}\right)$; 5yrGR = mean ring basal growth for five years $\left(\mathrm{mm}^{2}\right)$; $5 \mathrm{yrSE}$ $=$ standard error of 5yrGR.

health, and signs of emerald ash borer attack when compared to trees that survived (Table 2).

Model $_{\mathrm{A}}$ and Model $_{\mathrm{B}}$ returned correct predictions of survival and mortality in the $80 \%$ range (Table 3). For Model $_{\mathrm{A}}$ and Model $_{\mathrm{B}}, 66 \%$ and $60 \%$, respectively, of the incorrect predictions were trees that survived but were predicted to have died. Additionally, both models had similar separation of probability of mortality, which were significantly different for live and dead trees in both models. However, Model $_{B}$ had a lower AIC, indicating a better fit with the assessment data between these two models. Model $_{\mathrm{C}}$ and Model $_{\mathrm{H}}$ (identical resulting models) were similar in separating probabilities of mortality as $\mathrm{Model}_{\mathrm{A}}$ and Model $_{\mathrm{B}}$, but due to a greater AIC and lower correct prediction values, these two models $\left(\right.$ Model $_{\mathrm{C}}$ and Model $_{\mathrm{H}}$ ) were an overall poorer fit for the data. These two models had $64 \%$ of incorrect predictions in trees that actually survived. While Model $_{D}$ and Model $_{G}$ each had differences in the input variables for model 
development, the resulting model after pruning included only DBH (Table 3). Because of this single variable and single decision, these two models had the lowest AIC value. Even though the difference in the mean probability of mortality for live and dead trees for these two models was less than other successful models, the difference between means was still significant. However, this single variable model had the lowest correct prediction value, meaning it failed to correctly predict mortality in nearly a third of the assessment trees. Sixty percent of incorrect predictions were, again, in the trees that actually survived.
Model $_{\mathrm{E}}$ and Model $_{\mathrm{F}}$ returned a relatively high percentage of correct predictions for the assessment trees (Table 3). However, this is due to the issue that the model failed to predict any mortality, with a maximum probability of mortality $=0.29$. As a result of that issue, all of the trees would inherently be predicted to survive, exaggerating these model predictions. Further, because of their inability to predict mortality, the trees used to assess these models did not have significantly different probabilities of mortality. Overall, these two models $\left(\right.$ Model $_{\mathrm{E}}$ and Model $_{\mathrm{F}}$ ) could not differentiate between trees that would die and those that would survive.

Table 2. Model assessment trees that survived and died during 2009-2012 in Huron-Clinton Metroparks, Michigan, and 201 1-2014 in City of Fort Wayne Parks, Indiana.

\begin{tabular}{|c|c|c|c|c|c|c|}
\hline Assessment tree & Count & DBH & Crown dieback & Bark roughness & Vigor & With signs/symptoms \\
\hline Live & 81 & $18.3(1.5)$ & $9.4(1.4)$ & 2 & 1 & $42(51.9)$ \\
\hline Dead & 67 & $24.2(2.1)$ & $43.5(3.3)$ & 2 & 3 & $61(91.0)$ \\
\hline Test $^{z}$ & & -2.37 & -10.07 & 8.47 & 75.31 & 26.62 \\
\hline$P$-value & & 0.019 & $<0.001$ & 0.004 & $<0.001$ & $<0.001$ \\
\hline
\end{tabular}

${ }^{\mathrm{z}}$ Mean comparison with Student's t-test for means (DBH, crown dieback = 1-tailed); Mood's median test for bark roughness and vigor; and $\chi^{2}$ test for signs/symptoms.

Table 3. Decision models developed and assessed with trees from Huron-Clinton Metroparks, Michigan, and City of Fort Wayne Parks, Indiana.

\begin{tabular}{|c|c|c|c|c|c|c|c|}
\hline \multirow[t]{2}{*}{ Model code } & \multirow[t]{2}{*}{ Decision criteria } & \multirow[t]{2}{*}{$\begin{array}{l}\text { Correct } \\
(\%)\end{array}$} & \multirow[t]{2}{*}{ AIC } & \multicolumn{2}{|c|}{$\begin{array}{l}\text { Mean probability } \\
\text { of mortality }(\mathrm{SE})^{\mathrm{z}}\end{array}$} & \multirow[t]{2}{*}{$\mathrm{t}_{(2), 146}$} & \multirow[t]{2}{*}{$P$-value } \\
\hline & & & & Live & Dead & & \\
\hline Model $_{\mathrm{A}}$ & Percent crown dieback ${ }^{y}, \mathrm{DBH}^{\mathrm{x}}$, bark splits ${ }^{\mathrm{w}}$ & 83.8 & 3.15 & $\begin{array}{l}0.23 \\
(0.03)\end{array}$ & $\begin{array}{l}0.73 \\
(0.24)\end{array}$ & -11.04 & $<0.001$ \\
\hline Model $_{B}$ & Vigor rating ${ }^{\mathrm{v}}$, DBH, bark splits & 86.5 & 1.30 & $\begin{array}{l}0.22 \\
(0.03)\end{array}$ & $\begin{array}{l}0.76 \\
(0.20)\end{array}$ & -13.22 & $<0.001$ \\
\hline Model $_{\mathrm{C}}$ & Bark splits, DBH, woodpecker activity ${ }^{w}$ & 75.7 & 2.85 & $\begin{array}{l}0.29 \\
(0.03)\end{array}$ & $\begin{array}{l}0.63 \\
(0.23)\end{array}$ & -7.26 & $<0.001$ \\
\hline Model $_{D}{ }^{u}$ & $\mathrm{DBH}$ & 67.6 & -1.32 & $\begin{array}{l}0.44 \\
(0.02)\end{array}$ & $\begin{array}{l}0.58 \\
(0.17)\end{array}$ & -4.62 & $<0.001$ \\
\hline Model $_{\mathrm{E}}$ & Ten-year growth rate ${ }^{t}$ & 82.9 & 0.53 & $\begin{array}{l}0.04 \\
(0.02)\end{array}$ & $\begin{array}{l}0.10 \\
(0.00)\end{array}$ & $-1.14^{\mathrm{s}}$ & 0.261 \\
\hline Model $_{F}$ & Five-year standard errort, five-year growth rate $^{\mathrm{r}}$ & 82.9 & 0.53 & $\begin{array}{l}0.05 \\
(0.02)\end{array}$ & $\begin{array}{l}0.00 \\
(0.00)\end{array}$ & $-1.14^{\mathrm{s}}$ & 0.261 \\
\hline Model $_{G}{ }^{u}$ & $\mathrm{DBH}$ & 67.6 & -1.32 & $\begin{array}{l}0.44 \\
(0.02)\end{array}$ & $\begin{array}{l}0.58 \\
(0.17)\end{array}$ & -4.62 & $<0.001$ \\
\hline Model $_{\mathrm{H}}^{\mathrm{u}}$ & Bark splits, DBH, woodpecker activity ${ }^{w}$ & 75.7 & 2.85 & $\begin{array}{l}0.29 \\
(0.03)\end{array}$ & $\begin{array}{l}0.63 \\
(0.23)\end{array}$ & -7.26 & $<0.001$ \\
\hline
\end{tabular}

${ }^{\mathrm{z}}$ Calculated from the probability of mortality for each tree at the node terminus.

${ }^{y}$ Range $=5 \%-100 \%$.

${ }^{x}$ Diameter at breast height $(\mathrm{cm})$.

w Presence, absence $(1,0)$.

${ }^{v}$ Categorical 1-5 (1 healthiest, 5 poorest health).

${ }^{u}$ Model $_{D}$, Model $_{G}$, and Model ${ }_{H}$ included other variables as inputs but only DBH met the pruning protocol.

${ }^{\mathrm{t}}$ Mean ring basal area growth $\left(\mathrm{mm}^{2}\right)$.

${ }^{s} \mathrm{df}=33$.

${ }^{\mathrm{r}}$ Mean ring basal area standard error. 


\section{Mortality Year Model}

A model for predicting the year of mortality was developed from the output variables from the top three decision model criteria (e.g., percent dieback, $\mathrm{DBH}$, bark splits, and woodpecker activity) using the trees that died from the model development phase $\left(\right.$ Model $_{A}$, Model $_{B}$, and Model $_{C}$; Figure 3). This year prediction model had $71.6 \%$ correct prediction of mortality year of trees that died in the model assessment phase. The trees were significantly different in their predicted year of mortality $(F=4.85 ; \mathrm{df}=2,64$; $P=0.011$ ), with actualmortality Years 1 and 3 differing significantly in probability of mortality $(P=0.012)$.

\section{DISCUSSION}

Emerald ash borer has caused substantial mortality in ash in the Midwest United States (Poland and McCullough 2006). While some trees exhibit resiliency and survive infestation, many trees succumb to this pest (Marshall et al. 2013). Because of the prevalence of ash cultivars in street and park management, there is a definitive need to remove potentially hazardous trees to reduce the risk of public and personal property damage (MacFarlane and Meyer 2005). Due to the widespread use of ash as a street tree within the Midwest, the cost of full removal and replacement is beyond the budgets of municipalities and their street tree management agencies (Kovacs et al. 2010).

For the models presented here to be effective, they need to be easily implemented, accurately predict mortality, and effectively separate probability of mortality between groups of trees. The goal for these models was to assist in developing decision tools for managers, which would potentially lead to reducing the cost associated with full ash removal. Because of this goal, ease of model implementation is important. Measurements, such as $\mathrm{DBH}$ and rapid assessments of presence of emerald ash borer signs, can be effectively added to management training; likely, management and technicians already hold these skills. Accurate prediction of mortality is important in establishing the hierarchy of management (i.e., to remove or leave a tree).

Variable inclusion and exclusion from the final models were based on pruning models to a complexity parameter (0.02). Model $_{\mathrm{A}}$ and Model $_{\mathrm{B}}$ included both measurements any urban forester should be able to make in both $\mathrm{DBH}$ and a sign of emerald ash borer infestation (bark splits), as well as addi-

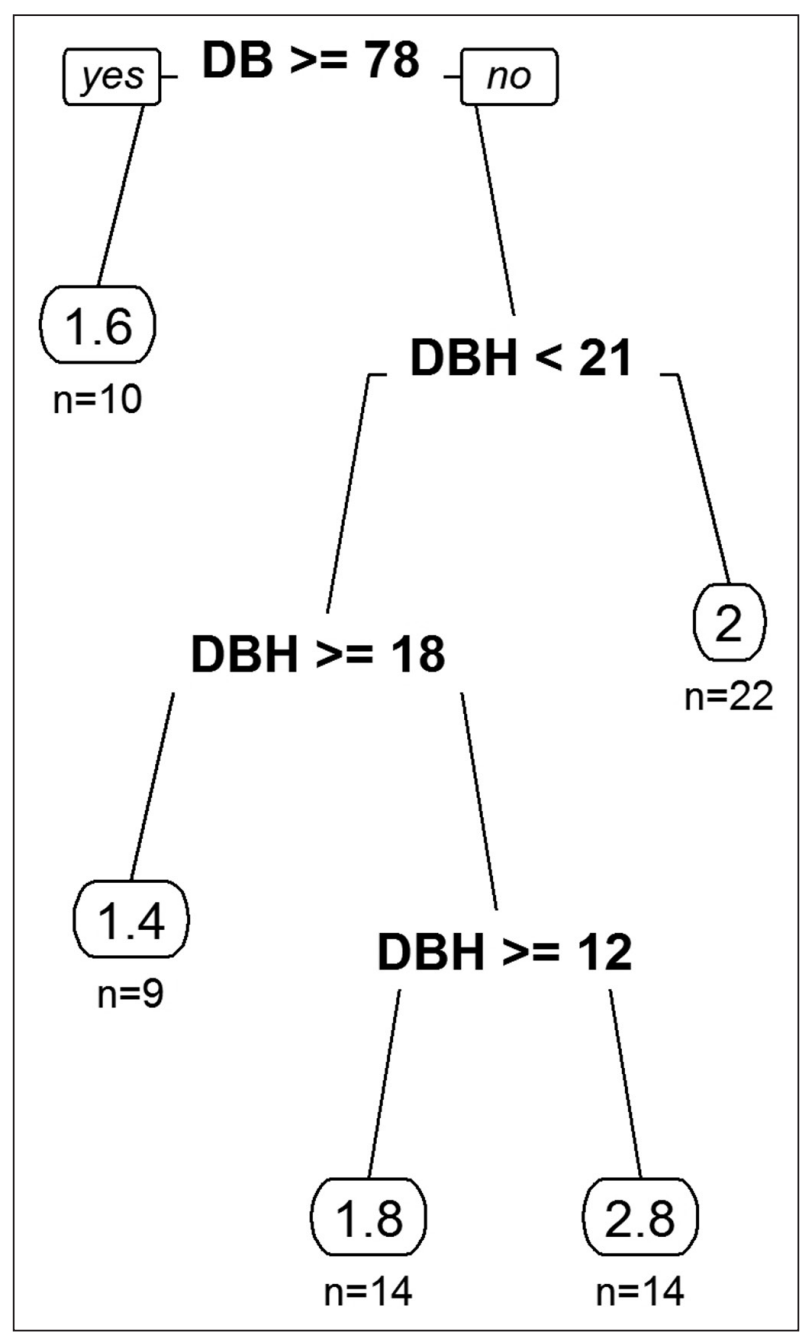

Figure 3. Graphical representation of mortality year decision model developed with trees from Huron-Clinton Metroparks, Michigan, and City of Fort Wayne Parks, Indiana, that succumbed to emerald ash borer during the three-year study period. Number of trees that reached the terminus of a branch is presented below the predicted year of mortality in ellipses. Variables include DB = percent crown dieback; DBH $=$ diameter at breast height $(\mathrm{cm})$.

tional assessments of overall tree health (percent dieback and vigor). Again, both of these models had relatively accurate predictions of mortality (both were $>83 \%$ correct). The majority of incorrect predictions for both Model $_{A}$ and Model $_{B}$ existed in falsely predicting a tree would die when in fact it survived. Finally, both Model $_{A}$ and Model $_{B}$ separated probabilities of mortality significantly; live trees had significantly lower probabilities of mortality than trees that died. Model $_{\mathrm{C} / \mathrm{H}}$ and Model $_{\mathrm{D} / \mathrm{G}}$ had substantially lower correct predictions of mortality, which greatly reduced their effectiveness. Also, $\operatorname{Model}_{\mathrm{E}}$ and $\operatorname{Model}_{\mathrm{F}}$ failed to separate the prob- 
abilities of mortality between live and dead trees because neither was able to predict any mortality, making both models ineffective and unusable.

Once trees were categorized as likely dying within the next three years, this year mortality model may add to fine-tuning management decisions. This model, however, may provide limited clarity in the mortality process. Since it could only successfully predict less than $72 \%$ of tree mortality years correctly, the application of this model may not provide tree managers with an effective decision tool.

As with other major environmental changes (e.g., drought, development), the interaction between tree location, land use, and mortality can be complex (Iakovoglou et al. 2001; Fahey et al. 2013). Interactions between soil type, drought conditions, compaction, and adjacent land-use may add to the error in prediction of ash mortality by emerald ash borer. However, the models presented here provide initial steps to establishing removal hierarchies within tree management agencies. By using the assessment variables in Model $_{\mathrm{A}}$ (percent crown dieback, $\mathrm{DBH}$, and presence of bark splits) or Model $_{B}$ (vigor rating, $\mathrm{DBH}$, and presence of bark splits), probability of potential mortality can be calculated relatively quickly and with reasonable accuracy. Removing trees that have the highest probabilities of dying within the immediate future (1-3 years), while retaining trees that will live beyond the next three years, would likely result in a potential financial benefit of distributing removal costs over several years.

\footnotetext{
Acknowledgments. We would like to thank the two anonymous reviewers whose comments helped improve the clarity of this manuscript. This work was supported in part by a John Z. Duling grant from the Tree Research and Education Endowment Fund. We would like to thank ongoing cooperation by the Huron-Clinton Metroparks and City of Fort Wayne Parks. Also, we would like to thank Cigdem Gurgur for review of preliminary work for this manuscript. Computational tools to implement these models are available online (http://users. ipfw.edu/marshalj/FSM).
}

\section{LITERATURE CITED}

Crook, D.J., A. Khrimian, J.A. Francese, I. Fraser, T.M. Poland, A.J. Sawyer, and V.C. Mastro. 2008. Development of a host-based semiochemical lure for trapping emerald ash borer Agrilus planipennis (Coleoptera: Buprestidae). Environmental Entomology 37:356-365.

de Groot, P., W.D. Biggs, D.B. Lyons, T. Scarr, E. Czerwinski, H.J. Evans, W. Ingram, and K. Marchant. 2006. A Visual Guide to Detecting Emerald Ash Borer Damage. Natural Resources Canada, Great Lakes Forestry Center, Sault Ste. Marie, Ontario, Canada.

Donovan, G.H., D.T. Butry, Y.L. Michael, J.P. Prestemon, A.M. Liebhold, D. Gatziolis, and M.Y. Mao. 2013. The relationship between trees and human health: Evidence from the spread of the emerald ash borer. American Journal of Preventive Medicine 44:139-145.

Fahey, R.T., M.B. Bialecki, and D.R. Carter. 2013. Tree growth and resilience to extreme drought across an urban land-use gradient. Arboriculture \& Urban Forestry 39:279-285.

Fayyad, U.M., and K.B. Irani. 1992. On the handling of continuousvalued attributes in decision tree generation. Machine Learning 8:87-102.

Friedl, M.A., and C.E. Brodley. 1997. Decision tree classification of land cover from remotely sensed data. Remote Sensing of Environment 61:399-409.

Haack, R.A., E. Jendek, H. Liu, K.R. Marchant, T.R. Petrice, T.M. Poland, and H. Ye. 2002. The emerald ash borer: A new exotic pest in North America. Newsletter of the Michigan Entomological Society $47: 1-5$.

Iakovoglou, V., J. Thompson, L. Burras, and R. Kipper. 2001. Factors related to tree growth across urban-rural gradients in the Midwest, USA. Urban Ecosystems 5:71-85.

Kovacs, K.F., R.G. Haight, D.G. McCullough, R.J. Mercader, N.W. Siegert, and A.M. Liebhold. 2010. Cost of potential emerald ash borer damage in U.S. communities, 2009-2019. Ecological Economics 69:569-578.

Kreutzweiser, D., K. Good, D. Chartrand, T. Scarr, and D. Thompson. 2007. Non-target effects on aquatic decomposer organisms of imidacloprid as a systemic insecticide to control emerald ash borer in riparian trees. Ecotoxicology and Environmental Safety 68:315-325.

MacFarlane, D.W., and S.P. Meyer. 2005. Characteristics and distribution of potential ash tree hosts for emerald ash borer. Forest Ecology and Management 213:15-24.

Marshall, J.M., E.L. Smith, R. Mech, and A.J. Storer. 2013. Estimates of Agrilus planipennis infestation rates and potential survival of ash. American Midland Naturalist 169:179-193.

Marshall, J.M., A.J. Storer, I. Fraser, J.A. Beachy, and V.C. Mastro. 2009. Effectiveness of differing trap types for the detection of emerald ash borer (Coleoptera: Buprestidae). Environmental Entomology 38:1226-1234.

Marshall, J.M., A.J. Storer, I. Fraser, and V.C. Mastro. 2010. Efficacy of trap and lure types for detection of Agrilus planipennis (Col., Buprestidae) at low density. Journal of Applied Entomology 134:296-302.

Millers, I., D. Lachance, W.G. Burkman, and D.C. Allen. 1991. North American sugar maple decline project: Organization and field methods. USDA Forest Service Gen. Tech. Rep. NE-154. Radnor, Pennsylvania, U.S. 26 pp. 
Mota-Sanchez, D., B.M. Cregg, D.G. McCullough, T.M. Poland, and R.M. Hollingworth. 2009. Distribution of trunk-injected 14C-imidacloprid in ash trees and effects on emerald ash borer (Coleoptera: Buprestidae) adults. Crop Protection 28:655-661.

Poland, T.M., and D.G. McCullough. 2006. Emerald ash borer: Invasion of the urban forest and the threat to North America's ash resource. Journal of Forestry 104:118-124.

Roman, L.A., E.G. McPherson, B.C. Scharenbroch, and J. Bartens. 2013. Identifying common practices and challenges for local urban tree monitoring programs across the United States. Arboriculture \& Urban Forestry 39:292-299.

Sargent, C., M. Raupp, D. Bean, and A.J. Sawyer. 2010. Dispersal of emerald ash borer within an intensively managed quarantine zone. Arboriculture \& Urban Forestry 36:160-163.

Siegert, N.W., D.G. McCullough, A.M. Liebhold, and F.W. Telewski. 2014. Dendrochronological reconstruction of the epicenter and early spread of emerald ash borer in North America. Diversity and Distributions 20:847-858.

Smitley, D.R., J.J. Doccola, and D.L. Cox. 2010a. Multiple-year protection of ash trees from emerald ash borer with a single trunk injection of emamectin benzoate, and single-year protection with an imidacloprid basal drench. Arboriculture \& Urban Forestry 36:206-211.

Smitley, D.R., E.J. Rebek, R.N. Royalty, T.W. Davis, and K.F. Newhouse. 2010b. Protection of individual ash trees from emerald ash borer (Coleoptera: Buprestidae) with basal soil applications of imidacloprid. Journal of Economic Entomology 103:119-126.

Szczepaniec, A., B.B. Raupp, and M.J. Raupp. 2013. Effects of dinotefuran and imidacloprid on target and non-target arthropods on American elm. Arboriculture \& Urban Forestry 39:231-235.

Yang, Z., X. Wang, J. Gould, and H. Wu. 2008. Host specificity of Spathius agrili Yang (Hymenoptera: Braconidae), an important parasitoid of the emerald ash borer. Biological Control 47:216-221.

Rachel E. Clark

Department of Biology

Indiana University-Purdue University Fort Wayne

Fort Wayne, Indiana 46805, U.S.

Kayla N. Boyes

Department of Biology

Indiana University-Purdue University Fort Wayne

Fort Wayne, Indiana 46805, U.S.

Lori E. Morgan

Department of Biology

Indiana University-Purdue University Fort Wayne

Fort Wayne, Indiana 46805, U.S.

Andrew J. Storer

School of Forest Resources and Environmental Science

Michigan Technological University

Houghton, Michigan 49931, U.S.

Jordan M. Marshall (corresponding author)

Department of Biology

Indiana University-Purdue University Fort Wayne

Fort Wayne, Indiana 46805, U.S.

marshalj@ipfw.edu
Résumé. L'agrile du frêne est un ravageur des frênes d'Amérique du Nord qui a provoqué une mortalité importante au sein des territoires où il s'est répandu. L'échéance de la mortalité des arbres, une fois infestés par l'agrile du frêne, est variable chez les arbres isolés, tandis qu'une petite proportion de ceux-ci survivent à l'infestation. Grâce à l'utilisation d'évaluations de santé des arbres et des signes connus d'infestation de l'agrile du frêne, les chercheurs ont développé des modèles décisionnels afin de prédire la probabilité de mortalité. Deux de ces modèles ont démontré une bonne performance et ont correctement prédit la mortalité (précision > 83\%), établissant de manière significative la probabilité de mortalité pour ces arbres. Les deux modèles prennent en compte le diamètre à hauteur de poitrine (DHP) et la présence de fissures dans l'écorce, le premier analysant en outre le pourcentage de dépérissement du houppier tandis que l'autre incluant la classe de vigueur de l'arbre (évaluation globale de la santé de l'arbre). Un troisième modèle a démontré une moindre prédiction de mortalité, mais constitue tout de même un modèle potentiellement efficace. Les autres modèles testés présentaient des lacunes dans la prédiction de mortalité ou dans la caractérisation des probabilités de mortalité. À partir des variables des trois modèles décisionnels retenus, l'année de la mortalité a été modélisée. Cependant, l’année spécifique de mortalité anticipée n’a pas été aussi efficace. En raison d'un large éventail de facteurs externes, la prédiction d'une année spécifique de mortalité peut ne pas être juste. Lutilisation du DHP, d'une évaluation rapide de l'état de santé et des données de l'infestation, les auteurs ont pu prédire avec justesse la mortalité des frênes à l'intérieur d'une période de trois ans pour la majorité des arbres visés par cette étude. Les stratégies de gestion qui utilisent ces modèles pour développer des programmes d’abattage progressif des frênes infestés peuvent ainsi amortir les coûts financiers et environnementaux sur plusieurs années par opposition à l'abattage de masse d'arbres de rues et de parcs.

Zusammenfassung. Der Eschenprachtkäfer ist ein Schädling der nordamerikanischen Esche, der eine signifikante Mortalität innerhalb seiner eingeführten Spannbreite verursacht. Das Zeitfenster für das Absterben des einmal durch den EAB infizierten Baumes ist für individuelle Bäume variabel, mit einer kleinen Anzahl von Bäumen, welche die Infektionen überlebten. Mithilfe von Baumgesundheitsuntersuchungen und Anzeichen von EAB-Infektionen, entwickelten die Forscher Entscheidungsmodelle, um die Wahrscheinlichkeit der Mortalität vorherzusagen. Zwei dieser Modelle erwiesen sich als tauglich bei der korrekten Vorhersage der Mortalität (>83\% korrekt) und unterschieden signifikant die Wahrscheinlichkeit der Mortalität dieser Bäume. Beide Modelle benutzen den Brusthöhendurchmesser (BHD) und das Auftreten von Rindenrissen, eins mit eingeschlossenem Prozentsatz an Kronenabsterben, das andere einschließlich Vitalitätsbeurteilung (allgemeine Gesundheitsbeurteilung). Ein drittes Modell hatte reduzierte korrekte Vorhersagen der Mortalität, aber es war potentiell noch ein effektives Modell. Andere getestete Modelle hatten Unzulänglichkeiten bei der Vorhersage der Mortalität oder bei der Unterscheidung der Wahrscheinlichkeit der Mortalität. Unter Verwendung der Variablen aus drei potentiellen Modellen wurde das Jahr der Mortalität modelliert. Dennoch waren spezifische Vorhersagen des Jahres nicht effektiv. Wegen einer breiten Bandweite von externen Faktoren dürfte eine präzise Vorhersage des Jahres der Mortalität nicht möglich sein. Unter Verwendung von BHD und Daten einer schnellen Gesundheits- und Infektionsuntersuchung waren die Autoren dieser Studie in der Lage, die Mortalität von Eschen innerhalb einer dreijährigen Periode für die Mehrzahl der Bäume innerhalb dieser Studie korrekt vorherzusagen. Managementstrategien, die diese Modelle für die Entwicklung von Programmen zu hierarchischen Fällungen infizierter Eschen verwenden, können die Kosten und Auswirkungen auf das Ökosystem über mehrere Jahre verteilen, im Gegensatz zu einer massenhaften Entfernung von Straßen- und Parkbäumen. 
Resumen. El barrenador esmeralda es una plaga del fresno de América del Norte que ha causado una mortalidad significativa dentro de su rango introducido. El plazo para la mortalidad de los árboles, una vez infestado por el barrenador esmeralda, es variable para los árboles individuales, con una pequeña posibilidad de sobrevivir a la infestación. Con el uso de evaluaciones de salud de los árboles y signos de infestación del barrenador esmeralda, los investigadores desarrollaron modelos de decisión para predecir la probabilidad de mortalidad. Dos modelos resultantes trabajaron bien para predecir la mortalidad (> 83\% correcto) y separando significativamente la probabilidad de mortalidad de estos árboles. Ambos modelos utilizan el diámetro a la altura del pecho (DAP) y la presencia de fracturas de la corteza, con una muerte regresiva de la copa y la otra calificación incluyendo el vigor (evaluación general de salud del árbol). Un tercer modelo había reducido correctamente la predicción de la mortalidad, pero seguía siendo potencialmente un modelo eficaz. Otros modelos probados tenían deficiencias en la predicción de la mortalidad o en la separación de las probabilidades de mortalidad. Usando variables de tres modelos de decisión fue modelado el año de mortalidad. Sin embargo, la predicción específica del año no fue tan eficaz. Debido a una amplia gama de factores externos, la predicción de un año específico de la mortalidad puede no ser apropiado. Mediante el uso de DAP y datos de muerte rápida e infestación, los autores fueron capaces de predecir correctamente la mortalidad de los fresnos en un plazo de tres años para la mayoría de los árboles dentro de este estudio. Las estrategias de gestión que utilizan estos modelos para el desarrollo de programas de eliminación jerárquicos de fresnos infestados pueden distribuir los costos financieros y ambientales a través de múltiples años en oposición a la retirada masiva de árboles de calles y parques urbanos. 